\title{
Strain performance of tilapia in freshwater prawn polyculture
}

\author{
M. S. R. Khan ${ }^{1}$, M. M. Khan ${ }^{2^{*}}$, N. Akter ${ }^{3}$ and M. A. Wahab ${ }^{3}$ \\ ${ }^{1}$ Department of Marine Bioresources Science, Chittagong Veterinary and Animal Sciences University, Chittagong \\ 4225; ${ }^{2}$ Department of Fisheries Biology and Genetics and ${ }^{3}$ Department of Fisheries Management Bangladesh \\ Agricultural University, Mymensingh-2202, Bangladesh, *E-mail: keya.3a@gmail.com
}

\begin{abstract}
Production performance of two tilapia (Oreochromis niloticus) strain viz. Chitralada and GIFT (Genetically Improved Farmed Tilapia) in fish-prawn polyculture system was compared, and possible effect of tilapia inclusion in freshwater prawn (Macrobrachium rosenbergii) culture was evaluated in 120 days of grow-out phase. There were three treatments, i.e. only freshwater prawn as control $\left(T_{1}\right)$, prawn + Chitralada $\left(T_{2}\right)$, and prawn + GIFT $\left(T_{3}\right)$ with three replications of each. Stocking densities for prawn juvenile was $30,000 \mathrm{ha}^{-1}$ in all the treatments and for both tilapia strains were $10,000 \mathrm{ha}^{-1}$. Floating feed containing $28 \%$ protein for tilapia and pelleted sinking feed for prawn were provided twice daily at a rate of $10-5 \%$ bw adjusted after each month of sampling. Water transparency was significantly lower $(\mathrm{P}<0.05)$ in treatment $\mathrm{T}_{1}$ with significantly higher chlorophyll- $\alpha$ content that increased with progression of time. Along with, plankton abundance was significantly higher $(P<0.05)$ in $T_{1}$ indicating prawn-tilapia mixed culture is better than traditional single species culture of prawn in terms of water quality management. Average individual weight, final weight, survival and production of prawn did not differ significantly $(P>0.05)$ among the treatments. In case of tilapia, average individual weight was significantly higher in Chitralada $(254.22 \mathrm{~g})$ than that of GIFT (201.52 g). However, survival of GIFT was significantly higher (92.50\%) than that of Chitralada (65.83\%). Gross and net production of tilapia did not vary significantly. It was concluded that prawn-tilapia mixed culture is advantageous over traditional mono culture regarding production augmentation, and tilapia inclusion improving water quality.
\end{abstract}

Keyword: Chitralada, GIFT tilapia, Strain, Freshwater prawn, Polyculture

\section{Introduction}

Increase of productivity through a more efficient utilization of the available natural food, is the most important aspect of polyculture (Hepher and Pruginin, 1981). Polyculture is the art of growing two or more compatible aquatic species with different feeding habits of spatial distribution together in a single waterbody (Zimmermann and New, 2000). In polyculture, combination of species that have different feeding niches increase overall production without a corresponding increase in the quantity of supplemental feed (Zimmermann and New, 2000). Thus, the system can improve water quality by creating a better balance among the microbial communities of the pond, resulting in enhanced production. Polyculture of tilapia (Orechromis nilotica) in prawn pond is now one of the most important techniques and can be a source of extra income for the poor fish farmers. Prawn (Macrobrachium rosenbergii) polyculture has a potentially higher net return than prawn monoculture (Rouse and Stickney, 1982). Culture of prawn with fish also improves the ecological balance of the pond water, preventing the formation of massive algal blooms (Cohen et al., 1983; Uddin et al., 2006).

$M$ rosenbergii is a benthophagic omnivore an excellent species for polyculture along with tilapia (Alam et al., 2001). Nile tilapia is omnivorous but feed predominantly on phytoplankton and can utilize blue-green algae (Beveridge and Baird, 2000). The attributes which makes Nile tilapia (O. niloticus) so suitable for fish farming are their general hardiness, great tolerance to adverse environmental conditions, ease of breeding, rapid growth rate, ability to efficiently convert organic and domestic wastes into high quality protein, and good taste (Pullin and Lowe-McConnell, 1982). Tilapia is considered as the most popular species of tilapia cultured around the globe (Ridha, 2011). For higher production, the GIFT (Genetically Improved Farmed Tilapia) strain was developed by the International Center for Living Aquatic Resources and Management (ICLARM) through several generation of selection from a base population involving eight different strains of Nile tilapia, Oreochromis niloticus (Eknath et al., 1993) and was imported in Bangladesh in the year 2005 (ADB, 2005). The Thai-Chitralada strain introduced to the Royal Chitralada Palace in Thailand in 1965 and originates from Egypt via Japan and this strain also performed parallel to other improved strain in grow-out (Yakupitiyage, 1998). Both the strains have higher potential to contribute in production augmentation in polyculture with the freshwater prawn. 
Though, both the tilapia strains are stocked by the farmers for higher production in commercial purpose but they may perform differently with the similar culture environment and investment. Nevertheless, the performance of different tilapia strains was not evaluated in Bangladesh context. Similarly, it can be positively presumed that the culture of freshwater prawn for export market and tilapia in the same pond for household consumption may be an innovative option for fish farmers. Contrariwise, tilapia may exhibit negative impact on prawn survival that may hamper total production (Garcia-Perez et al., 2000; Uddin et al., 2006). Therefore, we compared the growth performance of GIFT and Chitralada in freshwater prawn culture system with a view to finding better performed strain, and simultaneously, we evaluated the effect of tilapia addition on prawn production performance.

\section{Materials and Methods}

\section{Experimental design and site}

The experiment was conducted in a completely randomized design into 3 treatments with 3 replications of each in 9 earthen ponds $\left(80 \mathrm{~m}^{2}\right.$ each) at the Fisheries Field Laboratory of the Faculty of Fisheries, Bangladesh Agricultural University, Mymensingh for a period of 120 days from mid April to mid August 2009. Only prawn, prawn with GIFT and Prawn with Chitralada were stocked as treatment $T_{1}, T_{2}$ and $T_{3}$, respectively. Stocking density of prawn was $30,000 \mathrm{~h}^{-1}$ and tilapia as $10,000 \mathrm{~h}^{-1}$ in all treatments. The ponds were fenced by fine meshed synthetic net to protect rodents and escaping of prawn. The water depth was maintained around $1 \mathrm{~m}$, and two palm leaves were used as shelter of prawn juveniles in each pond.

\section{Pond Preparation and stocking}

All undesirable fishes were completely eradicated by drying of the ponds and aquatic weeds were removed manually. Lime $\left(\mathrm{CaCO}_{3}\right)$ was applied at a rate of $250 \mathrm{~kg} \mathrm{ha}^{-1}$ and fertilized 3 days after liming with urea and triple super phosphate (TSP) each at a rate of $25 \mathrm{~kg} \mathrm{ha}^{-1}$ after three days of liming. The juvenile of $M$. rosenbergii $(0.715 \mathrm{~g})$ were collected from Bangladesh Fisheries Research Institute, Mymensingh. Prawn juveniles were brought to the experimental site using plastic tanks equipped with aerators. The fry of Chitralada $(0.90 \mathrm{~g})$ were collected from a local hatchery at Kasinathpur, Pabna district and GIFT fry $(0.89 \mathrm{~g})$ were collected from local hatchery Agro-3 at Mymensingh district. In order to ensure the same age, fry of the same hatching date was collected and was transported to the experimental site through well-oxygenated air tight plastic bag.

\section{Post stocking management}

Floating feed for tilapia was provided 5 minutes before giving the sinking feed for prawn. Both were fed with pelleted feed containing $28 \%$ crude protein, daily at a rate of $10 \%$ of body weight for $1^{\text {st }}$ month, $8 \%$ for $2^{\text {nd }}$ month, $6 \%$ for the $3^{\text {rd }}$ month and $5 \%$ of body weight for rest of the cultured period. Half of the required ration for a day was supplied in the morning and rest half in the evening. Feed requirement were calculated and adjusted after each sampling of prawn once in a month.

\section{Water quality monitoring}

The transparency of water was measured by a Secchi disc of $20 \mathrm{~cm}$ diameter. Water temperature and dissolved oxygen was recorded by digital dissolved oxygen (DO) meter (YSI MODEL 58). pH was measured by a direct reading $\mathrm{pH}$ meter $(\mathrm{HACH})$ at the pond site. Plastic bottles with stopper having a volume of $250 \mathrm{ml}$ each and marked with pond number were used for collection of water samples. Water samples were collected by using a sampler designed in a manner that it was representative to all layers of the water column (vertical haul of the tube sampler covering about $1 \mathrm{~m}$ depth). Then the samples were transferred to the laboratory and $100 \mathrm{~mL}$ of water from each bottle was filtered through a glass microfibre filter paper (Whatman GF/C) with the help of an electric air pump for nutrient and chlorophyll- $\alpha$ analyses. Total alkalinity was determined using the titrimetric method (Stirling, 1985). Chlorophyll- $\alpha$ was determined using a spectrophotometer (Milton Roy Spectronic, Model 1001 plus, Rochester, NY, USA) after acetone extraction (Boyd, 1982). Nutrient analyses were performed using a HACH kit (model DR 2010, HACH, Loveland, CO, USA a direct reading spectrophotometer). Total alkalinity was determined by acid titration following Stirling (1985). 
For plankton samples, ten litres of water was sampled monthly from five different locations of each pond and filtered through a $25 \mathrm{~mm}$ meshed plankton net. Each filtered sample was transferred to a measuring cylinder and made up to a standard volume of $50 \mathrm{~mL}$ with distilled water and buffered formalin (10\%), and preserved in a sealed plastic bottle until analysis. Plankton was counted using a Sedgewick Rafter counting cell (S-R cell) under a binocular microscope (Olympus, M-4000D, Tokyo, Japan) following Stirling (1985). The quantitative estimation of plankton was done using the following (Stirling, 1985) equation:

$\mathrm{N}=(\mathrm{A} \times 1000 \times \mathrm{C}) /(\mathrm{V} \times \mathrm{F} \times \mathrm{L})$

Where, $\mathrm{N}=$ Number of plankton cells or units per liter of water, $\mathrm{A}=$ Total number of plankton counted, $\mathrm{C}=$ Volume of final concentrate of the sample in $\mathrm{ml}, \mathrm{V}=$ Area of field $\left(\mathrm{mm}^{2}\right), \mathrm{F}=$ Number of fields counted, $\mathrm{L}=$ Volume of original water in liter.

Tilapia and freshwater prawn was sampled monthly using seine net to assess their growth and health condition. At least 10 prawns from each pond were taken to make assessment of growth trends and to readjust feeding rate. Length and weight of prawn and sampled fish were measured using a measuring scale and digital electronic balance (OHAUS, MODEL No. CT-1200-S). Prawn and tilapia were handled carefully to avoid stress during sampling.

\section{Final harvesting of prawn and tilapia fish}

At $120^{\text {th }}$ day of stocking, water was pumped out from the ponds and all prawns and tilapias were harvested, weighed by an electronic balance and measured by a measuring scale. Weight gain per fish was calculated by deducting the average initial weight from the average final weight. The net production of each species was calculated by deducting stocked biomass from gross production (harvested biomass). Specific growth rate (SGR) was estimated as:

SGR = [Ln (final weight)-Ln (initial weight) $] \times 100 /$ culture period (days).

Survival rate of prawn and fish was calculated by the following formula:

Survival $(\%)=($ No. of harvested individual/ No. of stocked individual $) \times 100$

\section{Statistical analysis}

For the statistical analysis, significant variation among the means of the treatments were compared and determined through descriptive one-way analysis of variance (ANOVA) using the SPSS (Statistical Package for Social Science, version-16.0) and post-hoc analysis was done by Duncan Test. Independent two tailed $t$-test was performed to analyze the growth and production performance of tilapia. Significance was assigned at $0.05 \%$ level.

\section{Results and Discussion}

\section{Water quality parameters}

The mean values of each water quality parameter in different treatments are presented in Table 1 . The mean values of water temperature were $30.66 \pm 0.15,30.68 \pm 0.17$ and $30.69 \pm 0.18{ }^{\circ} \mathrm{C}$ in treatment $\mathrm{T}_{1}, \mathrm{~T}_{2}$ and $T_{3}$, respectively (Table 1). New (2000) stated that the optimum temperature range for $M$. rosenbergii is between 26 and $32{ }^{\circ} \mathrm{C}$. Temperature of pond water was found to be more or less similar in different treatments and was within suitable range $\left(21.9^{\circ} \mathrm{C}\right.$ to $\left.33.5^{\circ} \mathrm{C}\right)$ for prawn culture described by Fair and Foftner (1981). Water transparency was significantly lower in $T_{1}$ and followed decreasing pattern due to the absent of plankton feeding tilapia. Monthly variation in transparency among treatments is shown in the Fig. 1 and the linear regression analysis depicts monthly decreasing pattern of transparency in $T_{1}$. The mean values of water transparency of treatments $T_{1}, T_{2}$ and $T_{3}$ were $29.87 \pm 1.81,35.67 \pm 0.81$ and $35.93 \pm 0.97 \mathrm{~cm}$, respectively (Table 1 ). Transparency reading is about $20-30 \mathrm{~cm}$ indicating that water body is productive (Boyd, 1990). Wahab et al. (1995) reported that the transparency of productive water bodies should be $40 \mathrm{~cm}$ or less. 
Table 1. Mean $( \pm S E)$ water quality parameters as obtained under three treatments.

\begin{tabular}{|c|c|c|c|c|c|}
\hline \multirow{2}{*}{ Parameters } & \multicolumn{3}{|c|}{ Treatments } & \multirow{2}{*}{ F-Value } & \multirow[b]{2}{*}{ Significance } \\
\hline & $T_{1}$ & $\mathrm{~T}_{2}$ & $T_{3}$ & & \\
\hline Temperature $\left({ }^{\circ} \mathrm{C}\right)$ & $30.66 \pm 0.15$ & $30.68 \pm 0.17$ & $30.69 \pm 0.18$ & 0.006 & NS \\
\hline Transparency $(\mathrm{cm})$ & $29.87 \pm 1.81^{b}$ & $35.67 \pm 0.81^{\mathrm{a}}$ & $35.93 \pm 0.97^{\mathrm{a}}$ & 7.202 & $*$ \\
\hline Dissolved Oxygen $\left(\mathrm{mg} \mathrm{l}^{-1}\right)$ & $4.76 \pm 0.08$ & $4.83 \pm 0.09$ & $4.82 \pm 0.08$ & 0.202 & NS \\
\hline $\mathrm{pH}$ & $7.62 \pm 0.14$ & $7.42 \pm 0.11$ & $7.55 \pm 0.13$ & 0.653 & NS \\
\hline Alkalinity $\left(\mathrm{mg} \mathrm{I}^{-1}\right)$ & $50.00 \pm 3.53$ & $57.60 \pm 3.42$ & $56.53 \pm 3.78$ & 1.118 & NS \\
\hline $\mathrm{NO}_{3}\left(\mathrm{mg} \mathrm{l}^{-1}\right)$ & $0.027 \pm 0.0035^{a}$ & $0.018 \pm 0.002^{a b}$ & $0.020 \pm 0.002^{b}$ & 2.964 & * \\
\hline $\mathrm{PO}_{4}\left(\mathrm{mg} \mathrm{I}^{-1}\right)$ & $0.970 \pm 0.284$ & $1.179 \pm 0.401$ & $1.191 \pm 0.398$ & 0.115 & NS \\
\hline Chlorophyll- $\alpha\left(\mu \mathrm{g} \mathrm{I}^{-1}\right)$ & $0.0898 \pm 0.008^{\mathrm{a}}$ & $0.063 \pm 0.007^{b}$ & $0.058 \pm 0.007^{\mathrm{b}}$ & 5.492 & $*$ \\
\hline
\end{tabular}

Means with the different superscripts in same row are significantly different $(P<0.05)$

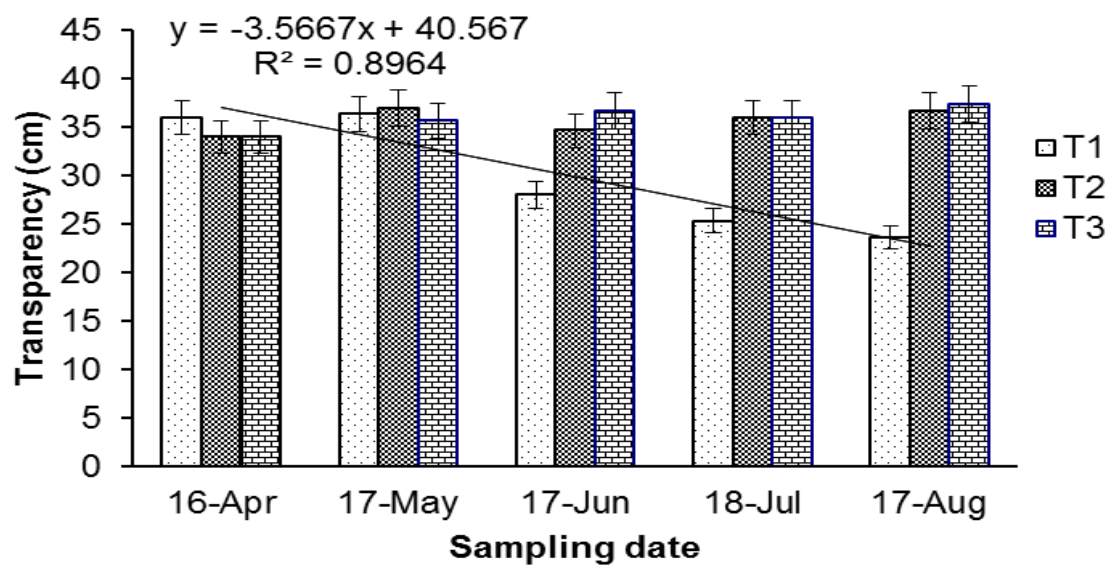

Fig. 1. Monthly variation in transparency among different treatments. The decreasing trend of the relationship between progressive sampling time and transparency is shown as linear regression line for $T_{1}\left(R^{2}=0.8964\right)$

The dissolved oxygen (DO) concentrations under different treatments were found to fluctuate from 4.45 to $5.44,4.88$ to 5.65 and 4.50 to $5.45 \mathrm{mg} \mathrm{l}^{-1}$ in treatment $\mathrm{T}_{1}, \mathrm{~T}_{2}$ and $\mathrm{T}_{3}$, respectively. The mean values of dissolved oxygen concentration in treatments $T_{1}, T_{2}$ and $T_{3}$ were 4.76 $\pm 0.08,4.83 \pm 0.09$ and $4.82 \pm 0.08$ $\mathrm{mg} \mathrm{I}^{-1}$ respectively. There was no significant difference $(P>0.05)$ among the treatments in terms of DO. Kunda et al. (2008) found dissolved oxygen level ranged from 5.98 to $6.53 \mathrm{mg} \mathrm{l}^{-1}$ in freshwater prawn polyculture.

The circum-neutral $\mathrm{pH}$ or slightly alkaline $\mathrm{pH}$ is most suitable for fish culture that range from 6.8 to 8.4 (Hossain et al., 2000). Tilapia seems to grow best in neutral or slightly alkaline water. pH values fluctuated from 7.0 to $7.9,6.7$ to 7.6 and 7.0 to 7.8 in treatment $T_{1}, T_{2}$ and $T_{3}$, respectively (Table 1). Mean values of $\mathrm{pH}$ were $7.6 \pm 0.14,7.4 \pm 0.11$ and $7.5 \pm 0.13$ in treatment $T_{1}, T_{2}$ and $T_{3}$, respectively. There was no significant difference $(P>0.05)$ among the treatments in terms of $\mathrm{pH}$.

According to Boyd (1982) total alkalinity should be more than $20 \mathrm{ppm}$ in fertilized ponds. Mean values of total alkalinity were $50.00 \pm 4.40,57.60 \pm 3.42$ and $56.53 \pm 3.78 \mathrm{mg} \mathrm{l}^{-1}$ in treatment $\mathrm{T}_{1}, \mathrm{~T}_{2}$ and $\mathrm{T}_{3}$, respectively. The highest value of total alkalinity was $64.93 \mathrm{mg} \mathrm{l}^{-1}$ in $\mathrm{T}_{2}$ and the lowest value was $32 \mathrm{mg} \mathrm{l}^{-1}$ in $\mathrm{T}_{1}$. Waterbodies having total alkalinity $40 \mathrm{ppm}$ or more are considered more productive than waterbodies of lower alkalinity (Mairs, 1966). The ranges of $\mathrm{NO}_{3}-\mathrm{N}$ were found to vary from 0.010 to $0.035,0.00$ to 0.023 and 0.010 to $0.025 \mathrm{mg} \mathrm{l}^{-1}$ in treatments $T_{1}, T_{2}$ and $T_{3}$, respectively. The mean values of $\mathrm{NO}_{3}-\mathrm{N}$ in ponds under treatments 1,2 and 3 were $0.027 \pm 0.004,0.018 \pm 0.002$ and $0.020 \pm 0.002 \mathrm{mg} \mathrm{I}^{-1}$ respectively. Concentration of $\mathrm{NH}_{3}$ was significantly higher in $\mathrm{T}_{1}$ than the other two treatments presumably due to lack of utilization by only a single species. Nitrate can accumulate in production systems without affecting fish growth (Heinsbroek and Kamstra et al., 1990) and tilapias can tolerant nitrate concentration of up to $0.45 \mathrm{mg} \mathrm{l}^{-1}$ (Chervinski, 1982). The $\mathrm{PO}_{4}-\mathrm{P}$ concentration ranged from 0.22 to 
$2.045 \mathrm{mg} \mathrm{I}^{-1}$ with the mean values of $0.971 \pm 0.284,1.179 \pm 0.402$ and $1.191 \pm 0.398 \mathrm{mg} \mathrm{l}^{-1}$ in $\mathrm{T}_{1}, \mathrm{~T}_{2}$ and $\mathrm{T}_{3}$, respectively. There was no significant difference $(P>0.05)$ among treatments when ANOVA was performed.

Chlorophyll- $\alpha\left(\mu \mathrm{g} \mathrm{I}^{-1}\right)$ value is an indicator of pond productivity shows an inverse relationship with water transparency (Ahmed, 1993). The level of chlorophyll $\alpha$ varied considerably throughout the experimental period, ranging from 0.011 to $0.107,0.022$ to 0.078 and 0.010 to $0.073 \mu \mathrm{g} \mathrm{I}^{-1}$ in treatments $\mathrm{T}_{1}, \mathrm{~T}_{2}$ and $\mathrm{T}_{3}$, respectively. Concentration of chlorophyll- $\alpha$ were significantly higher in treatment $T_{1}$, than in $T_{2}$ and $T_{3}$. In the treatment $T_{1}$, chlorophyll- $\alpha$ concentration increased with progression of time indicate prawn could not utilize all the phytoplankton and unutilized nutrient supported phytoplankton growth. Moreover, tilapia filters algae from the water column (Dempster et al., 1995). This was supported by significantly higher abundance of phytoplankton cells in $T_{1}$ and reflects that tilapia prevented the formation of massive algal blooms (Cohen et al., 1983). The mean values of chlorophyll- $\alpha$ were $0.090 \pm 0.008,0.063 \pm 0.007$ and $0.059 \pm 0.007 \mu \mathrm{g} \mathrm{I}^{-1}$ in treatments $\mathrm{T}_{1}, \mathrm{~T}_{2}$ and $\mathrm{T}_{3}$, respectively. The monthly variations of chlorophyll- $\alpha$ concentration under three treatments are shown in Fig. 2; the trend line is the linear regression line between respective sampling date and chlorophyll- $\alpha$ concentration $\left(R^{2}=0.7832\right)$ in $T_{1}$ that clearly depicts decreasing pattern. But this pattern was not observed in other two treatments.

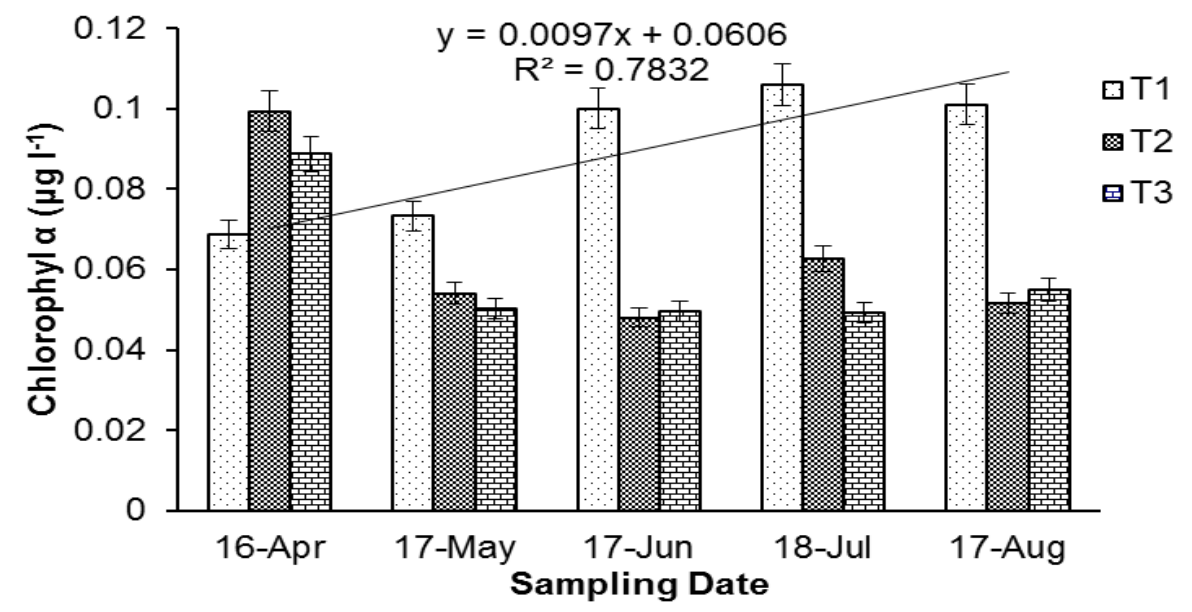

Fig. 2. Monthly variation of Chlorophyll- $\alpha$ among different treatments. The increasing trend of the relationship between progressive sampling time and transparency is shown as linear regression line for $T_{1}\left(R^{2}=0.7832\right)$

\section{Plankton and benthos study}

Mean abundance of plankton and benthos in different treatments are shown in Table 2. The mean abundance of total phytoplankton was $34633 \pm 2409$ indiv. $I^{-1}$ in $T_{1}, 27833 \pm 1767$ indiv. $I^{-1}$ in $T_{2}$ and $26367 \pm 2137$ indiv. $\mathrm{I}^{-1}$ in $\mathrm{T}_{3}$. Statistical analyses showed phytoplankton was significantly more abundant in prawn monoculture pond. Therefore, tilapia inclusion reduced plankton population in prawn-tilapia culture system. Nile tilapia ingests phytoplankton and can assimilate $70-80 \%$ of blue green algae which are hydrolyzed by acid digestion in the stomach (Moriarty, 1997; Bowen, 1982). The mean zooplankton concentration was $4633 \pm 418,4167 \pm 438$ and $4067 \pm 642$ indiv. $I^{-1}$ in $T_{1}, T_{2}$ and $T_{3}$, respectively. There was no significant difference $(P>0.05)$ among the treatments in terms of zooplankton abundance. Benthos population of the fish ponds was composed of four major groups: Chironomidae, Oligochaeta, Molluska and Miscellaneous. 
Table 2. Mean abundance \pm SE of plankton (cells $\left.\right|^{-1}$ ) as recorded from the ponds under different treatments $(\mathrm{N}=15)$

\begin{tabular}{lccccc}
\hline \multicolumn{1}{c}{ Groups } & Treatment- 1 & Treatment- 2 & Treatment- 3 & $F$-value & Significance \\
\hline Total phytoplankton & $34633 \pm 2409^{\mathrm{a}}$ & $27833 \pm 1767^{\mathrm{b}}$ & $26367 \pm 2137^{\mathrm{b}}$ & 4.325 & 0.020 \\
Total zooplankton & $4633 \pm 418$ & $4167 \pm 438$ & $4067 \pm 642$ & 0.352 & 0.705 \\
Total Plankton & $39267 \pm 2515^{\mathrm{a}}$ & $32000 \pm 1780^{\mathrm{b}}$ & $30433 \pm 2591^{\mathrm{b}}$ & 4.112 & 0.023 \\
Total Benthos & $1016 \pm 123$ & $1051 \pm 143$ & $948 \pm 101$ & 0.180 & 0.836 \\
\hline
\end{tabular}

Means with the different superscripts in same row are significantly different $(P<0.05)$

\section{Performance of prawn}

The growth rate and yield of prawn and fish in different treatments are shown in Table 3. Survival of prawn in different treatments varied from $60 \%, 65 \%$ and $67.64 \%$ in treatments $\mathrm{T}_{1}, \mathrm{~T}_{2}$ and $\mathrm{T}_{3}$ and did not vary significantly. Among the three treatments, the net production of prawn was higher in $\mathrm{T}_{3}(263.13 \pm$ $28.64 \mathrm{~kg} \mathrm{ha}^{-1} / 120$ days) than $T_{1}\left(251.06 \pm 23.74 \mathrm{~kg} \mathrm{ha}^{-1} / 120\right.$ days $)$ and $T_{2}\left(250.04 \pm 8.83 \mathrm{~kg} \mathrm{ha}^{-1} / 120\right.$ days $)$ respectively. Mean individual weight of prawn was $14.36 \pm 0.009,13.23 \pm 0.004$ and $13.26 \pm 0.003$ in treatments $T_{1}, T_{2}$ and $T_{3}$, respectively (Table 3). Therefore, tilapia inclusion in prawn pond had not any negative effect on prawn culture it might be due to in a polyculture setting, tilapia and prawn can utilize different niches in the culture setting. Tilapia can filter feed on phytoplankton and zooplankton in the upper water column but prawn spend most of the time in the pond bottom grazing on bacterial films on the bottom substrate and on the detritus settling from above.

Table 3. Comparison of Production performance (Mean $\pm S E$ ) among three treatments. Means with the different superscripts in same row are significantly different $(P<0.05)$. The independent samples two tailed $t$-test was performed for comparing production performance of two tilapia strains

\begin{tabular}{|c|c|c|c|c|}
\hline \multirow[b]{2}{*}{ Species \& Parameter } & \multicolumn{3}{|c|}{ Treatments } & \multirow[t]{2}{*}{ Significance } \\
\hline & $\begin{array}{c}\text { Prawn } \\
\left(T_{1}\right)\end{array}$ & $\begin{array}{c}\text { Prawn and } \\
\text { Chitralada }\left(\mathrm{T}_{2}\right)\end{array}$ & $\begin{array}{c}\text { Prawn and GIFT ( } \\
\left.\mathrm{T}_{3}\right)\end{array}$ & \\
\hline \multicolumn{5}{|l|}{ Prawn performance } \\
\hline Mean initial stocking weight $(\mathrm{g})$ & 0.727 & 0.725 & 0.725 & - \\
\hline Survival (\%) & 60 & 65 & 67.64 & 0.276 \\
\hline Mean final body weight (g) & $14.36 \pm 0.03$ & $13.23 \pm 0.68$ & $13.26 \pm 0.56$ & 0.038 \\
\hline SGR ( $\%$ body weight day $\left.{ }^{-1}\right)$ & 2.48 & 2.41 & 2.38 & 0.409 \\
\hline Gross production ( $\mathrm{kg} \mathrm{ha}^{-1}$ ) & $258.33 \pm 23.83$ & $257.29 \pm 8.87$ & $270.29 \pm 28.65$ & 0.657 \\
\hline Net production $\left(\mathrm{kg} \mathrm{ha}^{-1}\right)$ & $251.06 \pm 23.74$ & $250.04 \pm 8.83$ & $263.13 \pm 28.64$ & 0.676 \\
\hline Tilapia performance & & & & $t$-test \\
\hline Mean initial stocking weight $(\mathrm{g})$ & & 0.90 & 0.89 & - \\
\hline Survival (\%) & & $65.83^{\mathrm{b}}$ & $92.50^{\mathrm{a}}$ & 0.001 \\
\hline Mean final body weight (g) & & $254.22^{\mathrm{a}} \pm 17.28$ & $201.52^{\mathrm{b}} \pm 4.74$ & 0.042 \\
\hline SGR ( $\%$ body weight day ${ }^{-1}$ ) & & $4.7031^{a}$ & $4.5161^{\mathrm{b}}$ & 0.042 \\
\hline Gross production ( $\left.\mathrm{kg} \mathrm{ha}^{-1}\right)$ & & $1678.25 \pm 147.48$ & $1864.17 \pm 67.92$ & 0.316 \\
\hline Net production $\left(\mathrm{kg} \mathrm{ha}^{-1}\right)$ & & $1669.29 \pm 147.48$ & $1855.24 \pm 67.97$ & 0.321 \\
\hline \multicolumn{5}{|c|}{ Combine production performance } \\
\hline Gross production $\left(\mathrm{kg} \mathrm{ha}^{-1}\right)$ & $258.33 \pm 3.83^{b}$ & $1935.5 \pm 153.52^{a}$ & $2134.45 \pm 54.05^{a}$ & 0.001 \\
\hline Net production $\left(\mathrm{kg} \mathrm{ha}^{-1}\right)$ & $251.06 \pm 23.74^{b}$ & $1919.33 \pm 153.48^{a}$ & $2118.38 \pm 54.12^{a}$ & 0.001 \\
\hline
\end{tabular}

\section{Performance of Chitralada and GIFT}

Survival rate of GIFT tilapia was significantly higher $(P<0.05)(92.50 \%)$ than that of Chitralada $(65.83 \%)$ might be due to less transportation stress which also helped to gain the highest gross and net production of tilapia. Cebreros et al. (2013) observed, for tilapia, the highest survival was $94 \%$ and the lowest was $75 \%$, while prawns had final survival rates from $43 \%$ to $86 \%$ (Table 3 ). The specific growth rate (SGR) of GIFT tilapia was significantly lower $(P<0.05)$ in $T_{3}\left(4.52 \%\right.$ of bw day $\left.{ }^{-1}\right)$ than that of Chitralada in $T_{2}(4.70 \%$ of bw day $\left.{ }^{-1}\right)$. Average individual weight of Chitralada $(254.22 \mathrm{~g})$ was significantly higher than GIFT $(201.52 \mathrm{~g})$ presumably due to more genetically improved species and more environmental friendly. The highest gross and net production of tilapia was found in GIFT (1864.17 kg ha-1 $120^{-1}$ and $1855.24 \mathrm{~kg} \mathrm{ha}^{-1}$ $120^{-1}$ ) than Chitralada (1678.25 and $1669.25 \mathrm{~kg} \mathrm{ha}^{-1}$, respectively). The yields were not significantly 
different between the treatments. The mean weight of Chitralada was found $557.20 \mathrm{~g}$ and performed better than Red-stirling tilapia (Moreira et al., 2005). Similarly, no significant differences were found in grown and reproductive traits between Chitralada and GIFT traits (Bhujel, 2000; Yakupitiyage, 1998) Therefore, it may be concluded that the production performance between Chitralada and GIFT tilapia did not indicate significance difference but higher individual weight can be achieved from Chitralada and if transport stress can be minimized that would reduce mortality and increase production significantly.

The gross and net combine production of prawn and tilapia among the treatments (Table 3) were 258.33 $\mathrm{kg} \mathrm{ha}^{-1}$ and $251.06\left(\mathrm{~T}_{1}\right), 1935.5 \mathrm{~kg} \mathrm{ha}^{-1}$ and $1919.33 \mathrm{~kg} \mathrm{ha}^{-1}\left(\mathrm{~T}_{2}\right)$, and $2134.45 \mathrm{~kg} \mathrm{ha}^{-1}$ and $2118.38 \mathrm{~kg} \mathrm{ha}^{-1}$ $\left(\mathrm{T}_{3}\right)$. Prawn-tilapia polyculture increases total yield of fish and prawns (Garcia-Perez et al., 2000). Anggawa (1999) reported that yields of shrimp increased when tilapia were stocked into existing shrimp ponds. Polyculture of freshwater prawn with Nile tilapia was found successful (Mires, 1987) in terms of yield and income in a six months culture period. Cannibalism was only among prawns, which was not influenced by the presence of tilapia, and interactions were intra-specific in the polyculture systems. It was concluded that, prawn-tilapia mixed culture is better than traditional mono-culture of prawn and the performance of GIFT and Chitralada with prawn were not significantly different, but better individual weight can be gained from Chitralada by reducing transport stress.

\section{Conclusion}

The addition of tilapia in prawn pond benefited the freshwater prawn culture practices through (1) reducing exaggerating phytoplankton in waterbody (2) enhancing the utilization of natural foods in the form of plankton, periphyton, microbial organisms (3) enhancing water quality (4) improving survival, production and economic benefit. In a polyculture setting, tilapia and prawn can utilize different niches in the culture setting. Polyculture of prawn improved the ecological balance of the pond water, preventing the formation of massive algal bloom. Further research on the optimization of stocking densities of prawn and tilapia species is required to be emphasized based on improved strain for sustainable tilapia prawn aquaculture.

\section{References}

Ahmed, Z.F. 1993. Electivity index and dietary overlap of Catla catla in fertilized ponds of Bangladesh. An M.S. dissertation, Dept. of Fisheries Biology and Limnology, Bangladesh Agricultural University, Mymensingh. 163 pp.

Alam, M.J., Jahan, D.A., Pramanik, W.A. and Hoq, M.E. 2001. Polyculture of freshwater prawn, Macrobrachium rosenbergii, de Man with carps: effects of prawn stocking density. Bangladesh J. Fish. Res., 5(2): 135-144.

Anggawa, A. 1999. Polyculture of shrimp and tilapia in east Java. American Soybean Association (ASA) Technical Bulletin AQ471999.

Asian Development Bank (ADB). 2005. An Impact Evaluation of the Development of Genetically Improved Farmed Tilapia. Operations Evaluation Department, ADB, Manila, Philippines. 124pp.

Beveridge, M.C.M. and Baird, D.J. 2000. Diet, Feeding and Digestive Physiology. In: Beveridge, M.C.M. and B.J. McAndrew (Eds.) Tilapias: Biology and Exploitation, Kluwer Academic Publ., p. 59-87. New York, USA.

Bhujel, R.C. 2000. A review of strategies for the management of Nile tilapia (Oreochromis niloticus) broodfish in seed production systems, especially hapa-based systems. Aquaculture, 181: 37-59.

Bowen, S.H. 1982. Feeding digestion and growth-qualitative consideration. In: R.S.V. Pullin and Lowe McConnell, R.H. (Eds.). The biology and culture of tilapias. ICLARM conference proceedings, p. 141-156. International Center for Living Aquatic Resources Management, Manila, Philippines.

Boyd, C.E. 1982. Water Quality Management for Pond fish culture. Elsevier Science Publishers B.V., 1000 Amsterdam, The Netherlands. $318 \mathrm{pp}$.

Boyd, C.E. 1990. Water Quality in Ponds for Aquaculture. Birmingham Publishing Co. Bermingham, Alabama, USA. 477pp.

Cebreros A.R., García-Guerrero M., Molina P.A., Miranda A.S. 2013. A preliminary assay on the mixed culture of red Florida tilapia and freshwater prawn Macrobrachium americanum stocked in outdoor tanks at different tilapia densities. Agril. Sci., 4(7): 8. DOI:10.4236/as.2013.47050.

Chervinski, J. 1982. Environmental Physiology of Tilapias. In: R.S.V. Pullin and R.H. Lowe-Mcconnell, ed. The Biology and Culture of Tilapias. ICLARM Conference Proceedings 7, p. 119-128. International Center for Living Aquatic Resource Management, Manila, Philippines. 
Cohen, D., Ra'anan, Z., and Barnes, A. 1983. Production of the freshwater prawn Macrobrachium rosenbergii in Israel. I. Integration into fish polyculture system. Aquaculture, 31: 67-76.

Dempster, P., Baird, D.J. and Beveridge M.C.M. 1995. Can fish survive by filter-feeding on microparticles? Energy balance in tilapia grazing on algal suspensions. J. Fish Biol., 47(1): 7-17.

Eknath, A. E., Tayamen, M.M., Palada-de Vera, M.S., Danting, J.C., Reyes, R.A., Dionisio, E.E., Capili, J.B., Bolivar, H.L., Abella, T.A., Circa, A.V., Bentsen, H.B., Gjerde, B., Gjedrem, T. and Pullin, R.S.V. 1993. Genetic improvement of farmed tilapias: the growth performance of eight strains of Oreochromis niloticus tested in different farm environments. Aquaculture, 111: 171-188.

Fair, P.H. and Foftner, A.R. 1981. The role of formulated feeds on natural productivity in culture of the prawn, Macrobrachium rosenbergii. Aquaculture, 24: 233-243.

Garcia-Perez, A., Alston, D., and Cortes-Maldonado R. 2000. Growth, survival, yield and size distribution of freshwater prawn, Macrobrachium rosenbergii, and tilapia, Oreochromis niloticus, in polyculture and monoculture systems in Puerto Rico. J. World Aquacult. Soc., 31(3): 446-451

Heinsbroek, L.T.N. and Kamstra, A. 1990. Design and performance of water recirculation systems for eel culture. Aquacult. Eng., 9(3): 187-207.

Hepher, B. and Pruginin, Y. 1981. Commercial fish farming, with special reference to fish culture in Israel. Wiley Interscience, New York (USA). 261pp.

Hossain, M.A., Siddique, M.A.L. and Miaje, M.A.H. 2000. Development of low-cost feed for culture of giant freshwater prawn (Macrobrachium rosenbergii de Man) in ponds. Bangladesh J. Fish. Res., 4(2):127-134.

Kunda, M., Azim, M.E., Wahab, M.A., Dewan, S., Roos, N. and Thilsted, S.H. 2008. Potential of mixed culture of freshwater prawn (Mascrobrachium rosenbergii) and self-recruiting small species mola (Amblypharyngodon mola) in rottional rice-fish/prawn culture systems in Bangladesh. Aquacult. Res., 39: 506-517.

Mairs, D.F. 1966. A total alkalinity atlas for marine lake waters. Limnol. Oceanogr., 11: 68-72.

Mires, D. 1987. An improved polyculture management for freshwater prawns Macrobrachium rosenbergii and sex reversed Oreochromis niloticus. Bamidgeh, 39(4): 109-119.

Moreira, A.A., Moreira, H.L.M. and Hilsdorf, A.W.S. 2005.Comparative growth performance of two Nile tilapia (Chitralada and RedStirling), their crosses and the Israeli tetra hybrid ND-56. Aquacult. Res.,36(11):1049-1055.

Moriarty, D.J.W. 1997. The role of microorganisms in aquaculture ponds. Aquaculture, 151: 333-349.

New, M.B. 2000. Commercial freshwater prawn farming around the world. In: New, M.B. and W.C. Valenti, ed. Freshwater prawn culture: The farming of Macrobrachium rosenbergii, p. 290-325. Blackewll Science, UK.

Pullin, R., Lowe-McConnell, R. 1982. The Biology and Culture of Tilapias. The International Conference on the Biology and Culture of Tilapias. 1-351.

Ridha, M.T. 2011. Evaluation of monosex culture of GIFT and non-improved strains of Nile tilapia Oreochromis niloticus in recirculating tanks. Int. Aquacult. Res., 3: 189-195.

Rouse, D.B. and Stickney, R.R. 1982. Evaluation of the production potential of Macrobrachium rosenbergii in monoculture and in polyculture with Tilapia aurea. J. World Maricult. Soc., 13(1-4): 73-85.

Stirling, H.P. 1985. Chemical and Biological Methods of water Analysis for Aquaculturists. Institute of Aquaculture, University of Stirling, Scotland, UK.

Uddin M.S., Azim, M.E., Wahab, M.A. and Verdegem, M.C.J. 2006. The potential of mixed culture of genetically improved farmed tilapia (Oreochromis niloticus) and freshwater prawn (Macrobrachium rosenbergii) in periphyton-bsaed systems. Aquacult. Res., 37: 241-247.

Wahab, M.A., Ahmed, Z.F., Islam, M.A. and Rahmatullah, S.M. 1995. Effect of introduction of common carp, Cyprinus carpio (L) on the pond ecology and growth of fish in polyculture. Aquacult. Res., 26: 619-628.

Yakupitiyage, A. 1998. The bigger, the better: the tale of two tilapias. AARM Newsletter , 3(3): 9-11.

Zimmermann, S. and New, M.B. 2000. Growout systems-Polyculture and Integrated culture. In: New, M.B. and W.C. Valenti, ed. Freshwater Prawn Culture: The farming of Macrobrachium rosenbergii. p. 187-202. Blackwell Science Ltd., UK. 